\title{
Volume and Mass Estimation of Three-Phase High Power Transformers for Space Applications
}

Greg L. Kimnach

Glenn Research Center, Cleveland, Ohio 
Since its founding, NASA has been dedicated to the advancement of aeronautics and space science. The NASA Scientific and Technical Information (STI) Program Office plays a key part in helping NASA maintain this important role.

The NASA STI Program Office is operated by Langley Research Center, the Lead Center for NASA's scientific and technical information. The NASA STI Program Office provides access to the NASA STI Database, the largest collection of aeronautical and space science STI in the world. The Program Office is also NASA's institutional mechanism for disseminating the results of its research and development activities. These results are published by NASA in the NASA STI Report Series, which includes the following report types:

- $\quad$ TECHNICAL PUBLICATION. Reports of completed research or a major significant phase of research that present the results of NASA programs and include extensive data or theoretical analysis. Includes compilations of significant scientific and technical data and information deemed to be of continuing reference value. NASA's counterpart of peerreviewed formal professional papers but has less stringent limitations on manuscript length and extent of graphic presentations.

- TECHNICAL MEMORANDUM. Scientific and technical findings that are preliminary or of specialized interest, e.g., quick release reports, working papers, and bibliographies that contain minimal annotation. Does not contain extensive analysis.

- CONTRACTOR REPORT. Scientific and technical findings by NASA-sponsored contractors and grantees.
- CONFERENCE PUBLICATION. Collected papers from scientific and technical conferences, symposia, seminars, or other meetings sponsored or cosponsored by NASA.

- SPECIAL PUBLICATION. Scientific, technical, or historical information from NASA programs, projects, and missions, often concerned with subjects having substantial public interest.

- TECHNICAL TRANSLATION. Englishlanguage translations of foreign scientific and technical material pertinent to NASA's mission.

Specialized services that complement the STI Program Office's diverse offerings include creating custom thesauri, building customized databases, organizing and publishing research results ... even providing videos.

For more information about the NASA STI Program Office, see the following:

- Access the NASA STI Program Home Page at http://www.sti.nasa.gov

- E-mail your question via the Internet to help@sti.nasa.gov

- Fax your question to the NASA Access Help Desk at 301-621-0134

- Telephone the NASA Access Help Desk at 301-621-0390

- Write to:

NASA Access Help Desk

NASA Center for AeroSpace Information 7121 Standard Drive

Hanover, MD 21076 
NASA/TM-2004-213294

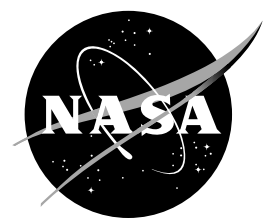

\section{Volume and Mass Estimation of Three-Phase High Power Transformers for Space Applications}

Greg L. Kimnach

Glenn Research Center, Cleveland, Ohio

Prepared for the

Second International Energy Conversion Engineering Conference sponsored by the American Institute of Aeronautics and Astronautics Providence, Rhode Island, August 16-19, 2004

National Aeronautics and

Space Administration

Glenn Research Center 
This report contains preliminary findings, subject to revision as analysis proceeds.

a

$\begin{array}{lr} & \text { Available from } \\ \text { NASA Center for Aerospace Information } & \text { National Technical Information Service } \\ \text { 7121 Standard Drive } & 5285 \text { Port Royal Road } \\ \text { Hanover, MD 21076 } & \text { Springfield, VA 22100 }\end{array}$

Available electronically at http:/ /gltrs.grc.nasa.gov 


\title{
Volume and Mass Estimation of Three-Phase High Power Transformers for Space Applications
}

\author{
Greg L. Kimnach \\ National Aeronautics and Space Administration \\ Glenn Research Center \\ Cleveland, Ohio 44135
}

\begin{abstract}
Spacecraft historically have had sub-1kW and communications: Galileo at $600 \mathrm{~W}_{\mathrm{e}}$, and Cassini at $900 \mathrm{~W}_{\mathrm{e}}$, for example. Because most missions have had the same order of magnitude power requirements, the Power Distribution Systems (PDS) use existing, space-qualified technology and are DC. As science payload and mission duration requirements increase, however, the required electrical power increases. Subsequently, this requires a change from a passive energy conversion (solar arrays and batteries) to dynamic (alternator, solar dynamic, etc.), because dynamic conversion has higher thermal and conversion efficiencies, has higher power densities, and scales more readily to higher power levels. Furthermore, increased power requirements and physical distribution lengths are best served with high-voltage, multi-phase AC to maintain distribution efficiency and minimize voltage drops. The generated AC-voltage must be stepped-up (or down) to interface with various subsystems or electrical hardware. Part of the trade-space design for AC distribution systems is volume and mass estimation of highpower transformers. The volume and mass are functions of the power rating, operating frequency, the ambient and allowable temperature rise, the types and amount of heat transfer available, the core material and shape, the required flux density in a core, the maximum current density, etc. McLyman [1] has tabulated the performance of a number of transformers cores and derived a "cookbook" methodology to determine the volume of transformers, whereas Schawrze [2] had derived an empirical method to estimate the mass of single-phase transformers. Based on the work of McLyman and Schwarze, it is the intent herein to derive an empirical solution to the volume and mass estimation of three-phase, laminated EI-core power transformers, having radiated and conducted heat transfer mechanisms available. Estimation of the mounting hardware, connectors, etc. is not included.
\end{abstract}

\section{Nomenclature}

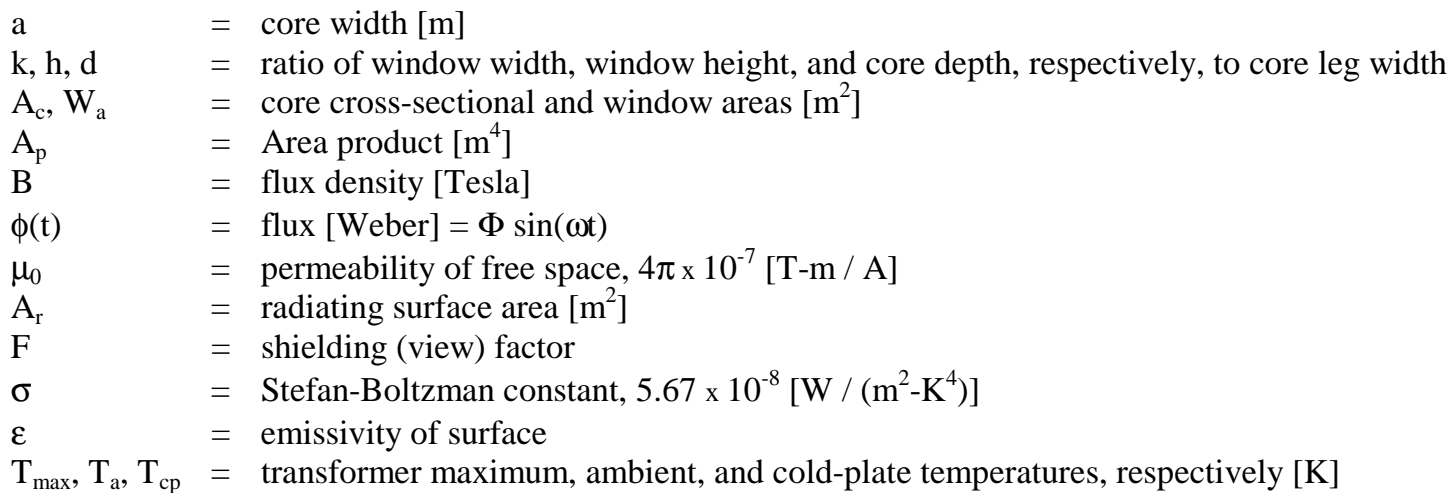

\section{Introduction}

DOWER transformers are used to change distribution voltage levels or to electrically isolate one system from another. The size and mass of the transformer is a function of many design trade-offs (e.g., core 
permeability/size versus efficiency) and design points (e.g., maximum operating temperature, power rating, and frequency). This paper is not intended to be a thorough transformer design treatise, but rather it presents an empirical solution to estimate the volume and mass of a three-phase, EI power transformer, which has only radiation and conduction heat transfer available and will operate at no more than $10 \mathrm{kHz}$. The method can be extended for other core geometries, material, as frequencies.

\section{Transformer Equations}

$\mathrm{T}_{\mathrm{n}}^{\mathrm{o}}$ estimate the volume of a transformer, the electrical, mechanical, and thermal performance for a given set of criteria must be derived.

\section{A. Electrical Equations}

The general voltage equations for a gapped, laminated EIcore, for which the dimensions are given in Figure 1, are derived for each phase. A voltage on the primary coils of each phase induces a time-varying flux, $\phi_{\mathrm{i}}(\mathrm{t})$, into the core. This flux links with the other windings and induces voltages in the secondary windings. Each phase winding is on an individual leg (i.e., one primary and one secondary per leg) and equally shares the window area with another phase. Phases 2 and 3 lag phase 1 by $120^{\circ}$ and $240^{\circ}$, respectively. With the gaps being equal, the

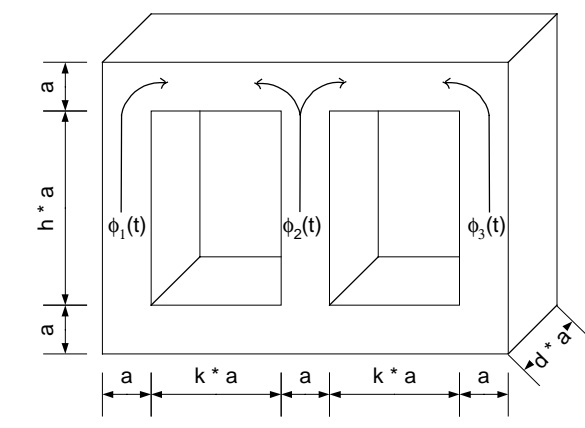

Figure 1. Mechanical dimensions and flux flow reluctance of each leg is equal and, therefore, the one-half of the flux induced by a primary winding flows in the other two legs. The resultant voltage equations for any winding of $n$-turns are given in Eq. (1).

$$
\begin{aligned}
& v_{1}(t)=n_{1} \frac{d}{d_{t}}\left\{\phi_{1}(t)-\frac{1}{2}\left[\phi_{1}\left(t-\frac{2 \pi}{3}\right)+\phi_{1}\left(t-\frac{4 \pi}{3}\right)\right\}\right. \\
& v_{2}(t)=n_{2} \frac{d}{d_{t}}\left\{\phi_{1}\left(t-\frac{2 \pi}{3}\right)-\frac{1}{2}\left[\phi_{1}(t)+\phi_{1}\left(t-\frac{4 \pi}{3}\right)\right\}\right. \\
& v_{3}(t)=n_{3} \frac{d}{d_{t}}\left\{\phi_{1}\left(t-\frac{4 \pi}{3}\right)-\frac{1}{2}\left[\phi_{1}(t)+\phi_{1}\left(t-\frac{2 \pi}{3}\right)\right\}\right.
\end{aligned}
$$

Simplification of Eqs. (1) by use of the following identities

$$
\begin{gathered}
\phi(t)=\Phi \sin (\omega t) \\
\frac{d}{d_{t}}[\sin (\omega t-\alpha)]=\omega \cos (\omega t-\alpha) \\
\cos (\mathrm{a}-\mathrm{b})=\cos (\mathrm{a}) \cos (\mathrm{b})+\sin (\mathrm{a}) \sin (\mathrm{b})
\end{gathered}
$$

results in expressions for the voltages:

$$
\begin{gathered}
v_{1}(t)=1.5 n_{1} \Phi \omega \cos (\omega t) \\
v_{2}(t)=1.5 n_{2} \Phi \omega \cos \left(\omega t-\frac{2 \pi}{3}\right) \\
v_{3}(t)=1.5 n_{3} \Phi \omega \cos \left(\omega t-\frac{4 \pi}{3}\right)
\end{gathered}
$$

From Fig. 1 it is seen that the cross-sectional area, $\mathrm{A}_{c}$, of the core equals $\mathrm{da}^{2}$. For a given core material the maximum, non-saturating flux density, $\hat{B}$, should not be exceeded. By definition $\Phi=\hat{B} * A_{c}$, and the root-mean square (rms) value of the primary and secondary voltages, using Eq. (2), can thus be expressed as

$$
\begin{aligned}
& V_{p}=\frac{1.5 N_{p} \omega \hat{B} A_{c}}{\sqrt{2}} \\
& V_{s}=\frac{1.5 N_{s} \omega \hat{B} A_{c}}{\sqrt{2}}
\end{aligned}
$$




\section{B. Fundamental parameter derivation}

The fundamental dimension, a [m], of the transformer core must be found. Equation 11.10 in McLyman's handbook relates the current density of the transformer to the area product. No distinction is made between primary or secondary current. Thus the rms-current densities are implied to be equal, $J_{p r i}=J_{\mathrm{sec}}=J\left[\mathrm{~A} / \mathrm{m}^{2}\right]$. This implies that each window area, $\mathrm{W}_{\mathrm{a}}$, must be shared equally by the windings within it. Because the primary and secondary of two phases share the window, we have: $W_{a, p}=W_{a, s}=\frac{W_{a}}{4}\left[\mathrm{~m}^{2}\right]$.

The ideal cross-sectional area of a winding is a function of the number of turns, $\mathrm{N}$, and the current density allowable within the window area (all four equal). Only a portion of the window can be filled with copper because of insulation and inter-winding gaps. This reduction is denoted as the window utilization factor, $\mathrm{k}_{\mathrm{u}}$. Thus, the ideal cross-sectional area of a single turn of a primary and a secondary winding is:

$$
\begin{aligned}
& A_{1}=\frac{k_{u} W_{a}}{4 N_{p}}\left[\mathrm{~m}^{2}\right] \\
& A_{2}=\frac{k_{u} W_{a}}{4 N_{s}}\left[\mathrm{~m}^{2}\right]
\end{aligned}
$$

Because Eq. (4) will probably not result in an actual AWG wire areas, the transformer design must be adjusted to accommodate the next-larger, actual AWG diameter, based on the wire diameter relationship for gage sizes stated by Fink \& Carroll [3].

The primary and secondary currents are fixed by the phase voltage and by the rated power of the transformer. A further constraint, which must be met, is based upon the relationship between $\mathrm{J}$ and the cross-sectional area of the conductor. Namely, $\mathrm{I}=\mathrm{J}_{\text {conductor, }}$, which leads to:

$$
\begin{aligned}
& I_{p}=\frac{J k_{u} W_{a}}{4 N_{p}}\left[\mathrm{~A}_{\mathrm{rms}}\right] \\
& I_{s}=\frac{J k_{u} W_{a}}{4 N_{s}}\left[\mathrm{~A}_{\mathrm{rms}}\right]
\end{aligned}
$$

The power of a three-phase transformer, operating in a balanced mode, is simply three times the power in any phase (i.e., $S_{\mathrm{rms}}=3 \mathrm{I}_{\mathrm{rms}} \mathrm{V}_{\mathrm{rms}}$ ). By substituting the voltage equations, Eq. (3), the current equations, Eq. (5), and McLyman's definition for the area product (i.e., $\mathrm{A}_{\mathrm{p}}=1.5 \mathrm{~W}_{\mathrm{a}} \mathrm{A}_{\mathrm{c}}\left[\mathrm{m}^{4}\right]$ ) into the power equation results in:

$$
\begin{aligned}
& S_{p}=3 I_{p} V_{p}=3 \frac{J k_{u} W_{a}}{4 N_{p}} \frac{1.5 N_{p} \omega \hat{B} A_{c}}{\sqrt{2}}=\frac{0.75}{\sqrt{2}} A_{p}\left(J \omega \hat{B} k_{u}\right) \text { [VA] } \\
& S_{s}=3 I_{S} V_{S}=3 \frac{J k_{u} W_{a}}{4 N_{s}} \frac{1.5 N_{s} \omega \hat{B} A_{c}}{\sqrt{2}}=\frac{0.75}{\sqrt{2}} A_{p}\left(J \omega \hat{B} k_{u}\right)[\mathrm{VA}]
\end{aligned}
$$

For an ideal, loss-less transformer, the output power equals the input power and, thus, either expression in Eq. (6) can be used to solve for $A_{p}$. The resulting expression for $A_{p}$ as a function of the rated power, electrical frequency, actual current density within the conductors, the core utilization factor, and the peak flux density is:

$$
A_{p}=\frac{4}{3} \frac{\sqrt{2} S_{\text {rated }}}{J \omega B k_{u}}\left[m^{4}\right]
$$

Having found an expression for $\mathrm{A}_{\mathrm{p}}$, the fundamental core dimension "a" can be found as follows:

$$
\begin{aligned}
A_{p} & =1.5 W_{a} A_{c}\left[\mathrm{~m}^{4}\right] \\
& =1.5\left(h k a^{2}\right)\left(d a^{2}\right) \\
A_{p} & =1.5 d h k a^{4} \quad\left[\mathrm{~m}^{4}\right] \\
\therefore a & =\sqrt[4]{\frac{2 A_{p}}{3 d h k}} \quad[\mathrm{~m}]
\end{aligned}
$$




\section{Copper and core losses}

The transformer losses are the sum of the copper and core losses. First, the copper losses will be determined. By definition $\mathrm{R}=\rho \mathrm{L} / \mathrm{A}$, where $\mathrm{A}$ is the cross-sectional area $\left[\mathrm{m}^{2}\right]$ of a conductor, $\rho$ is the conductor's electrical resistivity $[\Omega-\mathrm{m}]$, and $\mathrm{L}$ is the total length $[\mathrm{m}]$. Having found the cross-sectional area of the winding per Eq. (4), the total length of a winding must be found. To accomplish this, the Mean Length of a Turn, MLT, of an n-turn winding (whether primary or secondary) is found according to:

$$
M L T=\frac{\text { Total length }}{\text { turns }}=\frac{l_{\max }+l_{\min }}{2} \quad[\mathrm{~m}]
$$

From Fig. 2 the MLT can be approximated as follows. Assume that a 0 -diameter wire is bent at $90^{\circ}$ angles, then the innermost $\left[1_{\min }\right]$ and outermost $\left(1_{\max }\right)$ winding lengths are:

$$
\begin{aligned}
& l_{\text {min }}=2 a(1+d) \quad[\mathrm{m}] \\
& l_{\text {max }}=2 a\{(k+d)+(k+1)\}=2 a(2 k+d+1) \quad[\mathrm{m}]
\end{aligned}
$$

Substituting these lengths and Eq. (8) into Eq. (9) and simplifying results in an expression for the MLT:

$$
\begin{aligned}
M L T & =2 a(k+d+1) \\
& =2(k+d+1) \sqrt[4]{\frac{2 A_{p}}{3 d h k}}[\mathrm{~m}]
\end{aligned}
$$
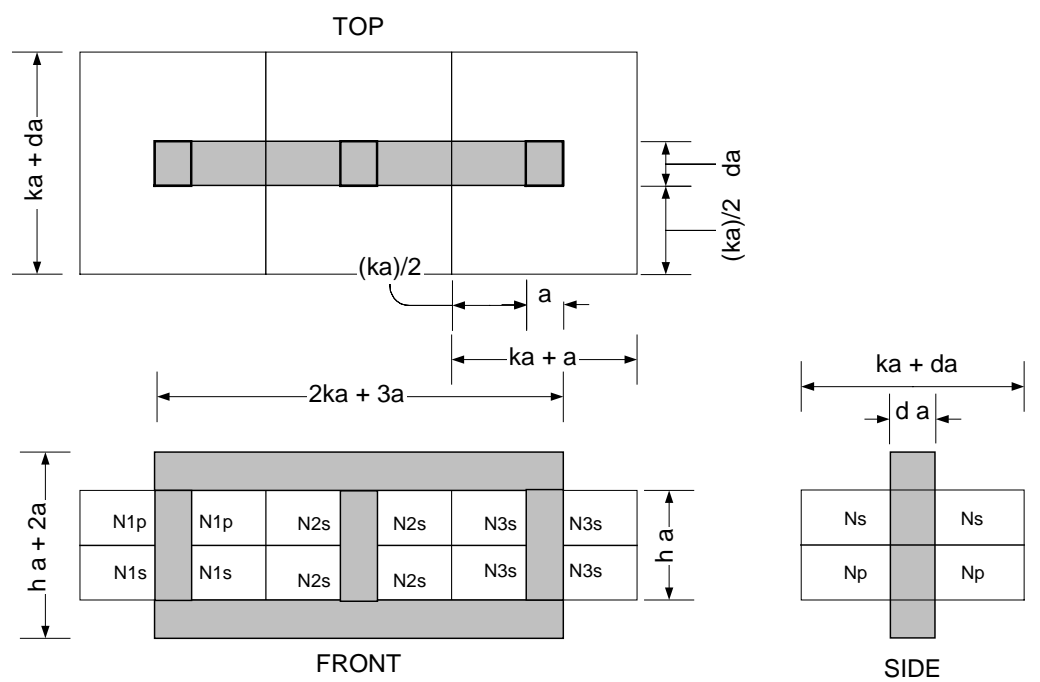

Figure 2. Transformer dimensions with windings.

Now the total copper loss, ignoring skin effect in this derivation, for the three phases is:

$$
\begin{aligned}
P_{C u} & =3\left(I_{p}^{2} R_{p}+I_{s}^{2} R_{s}\right)[W] \\
& =3\left[\left(\frac{J k_{u} W_{a}}{4 N_{p}}\right)^{2}\left[\rho \frac{M L T N_{p}}{\frac{k_{u} W_{a}}{4 N_{p}}}\right]+\left(\frac{J k_{u} W_{a}}{4 N_{s}}\right)^{2}\left[\rho \frac{M L T N_{s}}{\frac{k_{u} W_{a}}{4 N_{s}}}\right]\right] \\
& =1.5 J^{2} W_{a} k_{u} \rho M L T \\
\therefore & P_{C u}=3 J^{2} k_{u} \rho \sqrt{\frac{2 h k A_{p}}{3 d}} \sqrt[4]{\frac{2 A_{p}}{3 d h k}}(k+d+1) \quad[\mathrm{W}]
\end{aligned}
$$

The core loss is the sum of the hysteresis and eddy current losses, and can be approximated over the range of frequencies of interest as [4]: 


$$
\begin{aligned}
& P_{\text {hysteresis }}=\text { Volume }_{\text {core }} k_{h} \hat{B^{1.6}} f[\mathrm{~W}] \\
& P_{\text {eddy }}=\text { Volume }_{\text {core }} k_{e} t^{2} f^{2} \hat{B^{2}}[\mathrm{~W}]
\end{aligned}
$$

The lamination thickness, $\mathrm{t}[\mathrm{m}]$, is set at $90 \%$ of the skin depth, which is a function of frequency and of the relative permeability and resistivity of the material. The minimum value allowed is 0.007 " $(0.18[\mathrm{~mm}])$, and is found according to Eq. (14).

$$
t(f)=\sqrt{\frac{\rho}{\pi f \mu_{r} \mu_{0}}} \geq 0.18[\mathrm{~mm}]
$$

The core volume is found from Fig. (2) to be:

$$
V_{\text {core }}=(h a+2 a)(3 a+2 k a) d a-2(k a)(h a)(d a)=d(3 h+4 k+6) a^{3} \quad\left[\mathrm{~m}^{3}\right]
$$

Substitution for the core volume into Eq. $(12,13)$, summing, substituting Eq. 8, and simplifying leads to the core power loss to be:

$$
P_{\text {core }}=d(3 h+4 k+6)\left(\frac{2 A_{p}}{3 d h k}\right)^{\frac{3}{4}} f\left(k_{h} B^{\hat{1.6}}+k_{e} t^{2} f \hat{B^{2}}\right) \quad[\mathrm{W}]
$$

The electrical equations are complete. However, if these were used to solve the transformer volume, without considering the heat dissipation and maximum temperature limitations of a physical device, the solution would be an unrealistically small transformer. Therefore, the heat rejection must be estimated.

\section{Heat Rejection Equations}

A transformer's size is a function of its efficiency (power loss) and the ability to reject heat to the environment, among other variables. Heat transfer methods are radiation, convection (moving fluids), and conduction (solids). For space applications convective heat transfer to the surroundings is non-existent. For the volume estimation problem, heat rejection is thus limited to radiation and conduction through the core to the cold plate. Furthermore, the surface temperature of the cold plate is assumed to be constant.

The heat transfer for non-black body surfaces is given by:

$$
P_{\text {rad }}=F A_{r} \varepsilon \sigma\left(T_{\max }^{4}-T_{a}^{4}\right) \quad[\mathrm{W}]
$$

It is the assumed that the transformer is enclosed with a shielding factor of 0.9. Transformer surfaces are assumed to not radiate heat to other surfaces of the transformer. The exposed area of the transformer is defined as the total surface area less the surface area in contact with the cold plate. From Fig. (2) the total surface area of the transformer can be found:

$$
\begin{gathered}
\mathrm{A}_{\mathrm{SA}}=2(\mathrm{ka}+\mathrm{da})(3 \mathrm{ka}+3 \mathrm{a})+4(2 \mathrm{ka}+3 \mathrm{a}) \mathrm{a}+4 \mathrm{da}^{2}+2 \mathrm{ha}(3 \mathrm{ka}+3 \mathrm{a})+2 \mathrm{ha}(\mathrm{ka}+\mathrm{da}) \\
A_{S A}=2 a^{2}\left(3 k^{2}+7 k+3 d k+5 d+6+4 h k+3 h+h d\right) \quad\left[\mathrm{m}^{2}\right]
\end{gathered}
$$

And the area of the core in contact with the cold plate is

$$
A_{\text {top_core }}=d a(2 k a+3 a)=a^{2}(2 d k+3 d)\left[\mathrm{m}^{2}\right]
$$

By subtracting Eq. (18) from Eq. (17), the surface area available for radiation heat transfer is

$$
\begin{aligned}
& A_{r}=a^{2}\left(6 k^{2}+14 k+4 d k+7 d+12+8 h k+6 h+2 h d\right) \\
& A_{r}=\sqrt{\frac{2 A p}{3 d h k}}\left(6 k^{2}+14 k+4 d k+7 d+12+8 h k+6 h+2 h d\right)\left[\mathrm{m}^{2}\right]
\end{aligned}
$$

As a result, the expression for radiated heat transfer becomes: 


$$
P_{r a d}=F \sqrt{\frac{2 A p}{3 d h k}}\left(6 k^{2}+14 k+4 d k+7 d+12+8 h k+6 h+2 h d\right) \varepsilon \sigma\left(T_{\max }^{4}-T_{a}^{4}\right)[\mathrm{W}]
$$

Because the transformer surfaces will not have convective heat transfer available (i.e., no moving air), the cold plate must transfer the heat flux, which is not radiated. Cold plates have two heat transfer modes: conduction and convection. Heat is conducted through the core, across interface, and through the cold plate to the coolant interface. Heat transfer from the cold plate material to the moving coolant is via convection. This is not a cold plate design. Therefore, it will be assumed that the cold plate is designed to maintain the cold plate surface at a constant and uniform temperature, $\mathrm{T}_{\mathrm{cp}}$. To further simplify the problem, it will be assumed that all of the heat flux conducted within the transformer begins at a surface area of uniform temperature (the maximum

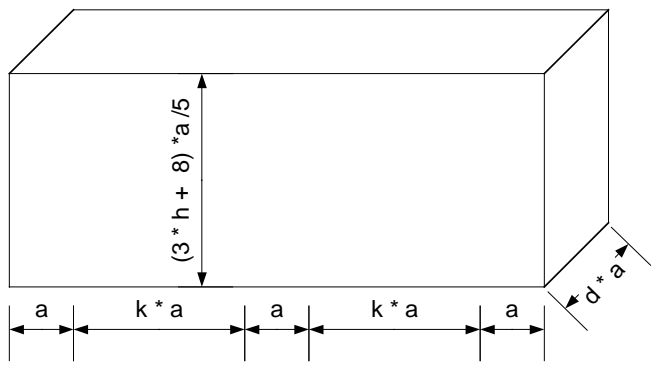

Figure 3. Equivalent core mass for heat transfer

allowed). This heat flux is uniformly distributed at one end of an equivalent solid core, having no windows areas and has a height equal to the mean height of the core as shown in Fig. (3). All heat flux must pass through this volume to the cold plate. Lastly, the contact surface area is that given in Eq. (18).

The conducted heat transfer capacity, $\mathrm{P}_{\text {cond }}$, of this equivalent core mass with a given thermal conductivity, $\tau_{\mathrm{c}}$ [W/m-C], is given by:

$$
P_{\text {cond }}=\frac{\left(T_{\max }-T_{c p}\right) \tau_{c} A_{c p}}{\text { mean height }}[\mathrm{W}]
$$

Substituting for the bottom surface area of the cold plate and for the mean height, the expression for the thermal energy transferred by the core to the cold plate is:

$$
P_{\text {cond }}=\frac{5\left(T_{\max }-T_{c p}\right) \tau_{c} \sqrt[4]{\frac{2 A p}{3 d h k}} *(2 d k+3 d)}{3 h+10}[\mathrm{~W}]
$$

The thermal losses must equal the heat transfer system design capacity to limit the fully loaded transformer to its maximum operating temperature. This can be written as

$$
\mathrm{P}_{\text {core }}+\mathrm{P}_{\mathrm{Cu}}=\mathrm{P}_{\text {cond }}+\mathrm{P}_{\mathrm{rad}}[\mathrm{W}]
$$

\section{E. The system of Equations}

The transformer problem consists of a system of equations (i.e., Eqs. 7, 11, 15, 20, and 22) subject to further constraints (i.e., Eq. 23, h $>0, \mathrm{~d}>0, \mathrm{k}>0, J \leq J_{\max }$ ). From the solution of this system of equations all other parameters can be found. For example, "a" is found according to Eq. (8), MLT by Eq. (10), Np from Eq. (3a), etc. Also, having found $\mathrm{N}_{\mathrm{p}}$ and $\mathrm{N}_{\mathrm{s}}$, the wire gage can be determined according to Eq. (3a) and the transformer ratio, since 2 primary and 2 secondary windings share the window and have a given utilization factor. Now all of the parameters are available to estimate the mass, dimensions, and volume of the transformer copper and core as a function of it power, voltage, and temperature constraints.

\section{Sample Estimation Results}

A 50kVA, three-phase, 400V:400V isolating transformer is designed to operated with $1.5[\mathrm{~T}], \quad \mathrm{J}_{\max }=3.5 \times 10^{6}\left[\mathrm{~A} / \mathrm{m}^{2}\right]$, and the laminations are a function of frequency, but limited to a minimum of $0.18[\mathrm{~mm}]$. The core has parameters of $\mu_{\mathrm{r}}=1000, \rho=9.579 \times 10^{-8}[\Omega-\mathrm{m}]$, and a density of $7300\left[\mathrm{~kg} / \mathrm{m}^{3}\right]$. The windings are copper for which $\rho=1.724 \times 10^{-8}[\Omega-\mathrm{m}]$ and density $=8890\left[\mathrm{~kg} / \mathrm{m}^{3}\right]$. The window utilization
Table 1. 50kVA transformer volume and mass Estimates

$\begin{array}{lrrr}\mathrm{f}[\mathrm{Hz}] & 50 & 1000 & 1500 \\ \text { volume }\left[\mathrm{cm}^{\wedge} 3\right] & 34525 & 9947 & 8887 \\ \text { Length }[\mathrm{mm}] & 416 & 468 & 458 \\ \text { Height }[\mathrm{mm}] & 316 & 192 & 103 \\ \text { Depth }[\mathrm{mm}] & 262 & 110 & 187 \\ \text { mass }[\mathrm{kg}] & 169 & 28 & 25\end{array}$


is assumed to be $40 \%$. The ambient, cold plate, and maximumoperating temperatures are $303 \mathrm{~K}, 293 \mathrm{~K}$, and $333 \mathrm{~K}$, respectively.

The transformer mass and dimensions-excluding mounting hardware, etc. - is shown as a function of frequency in Fig. (4). Furthermore, a comparison of the estimates for the $50 \mathrm{kVA}$ transformer operating at $50 \mathrm{~Hz}, 1000 \mathrm{~Hz}$, and $1500 \mathrm{~Hz}$ are given in Table 1.

\section{Conclusion}

An empirical solution has been derived to estimate the volume and mass of cut-core, E-I, high-power transformers to be used in space applications, and have only radiation and cold-plate cooling available and must be sized to operate within the prescribed operating limits. Mounting hardware and connectors are not estimated, and the estimation is not an optimization of the transformer design. Furthermore, using the derivation steps in this paper, it should be possible to adapt the procedure to other core shapes and materials.

\section{References}

${ }^{1}$ McLyman, William T., Transformer and Inductor Design Handbook, $2^{\text {nd }}$ ed., Marcel Dekker, Inc., 1988.

${ }^{2}$ Schwarze, Gene E., "Development of High Frequency Low Weight Power Magnetics for Aerospace Power-Systems," Proceedings of IECEC, Volume 1, San Francisco, CA, 1984, pp. 196-204.

${ }^{3}$ Fink, Donald G.,Carroll, John M., Standard Handbook for Electrical Engineers, page 4-19, Tenth ed., McGraw Hill Book Company, 1969.

${ }^{4}$ Lipo, T.A., Introduction to AC Machine Design, Vol. 1. Wisconsin Power Electronics Research Center, University of Wisconsin., 1996. pp. 267-273.
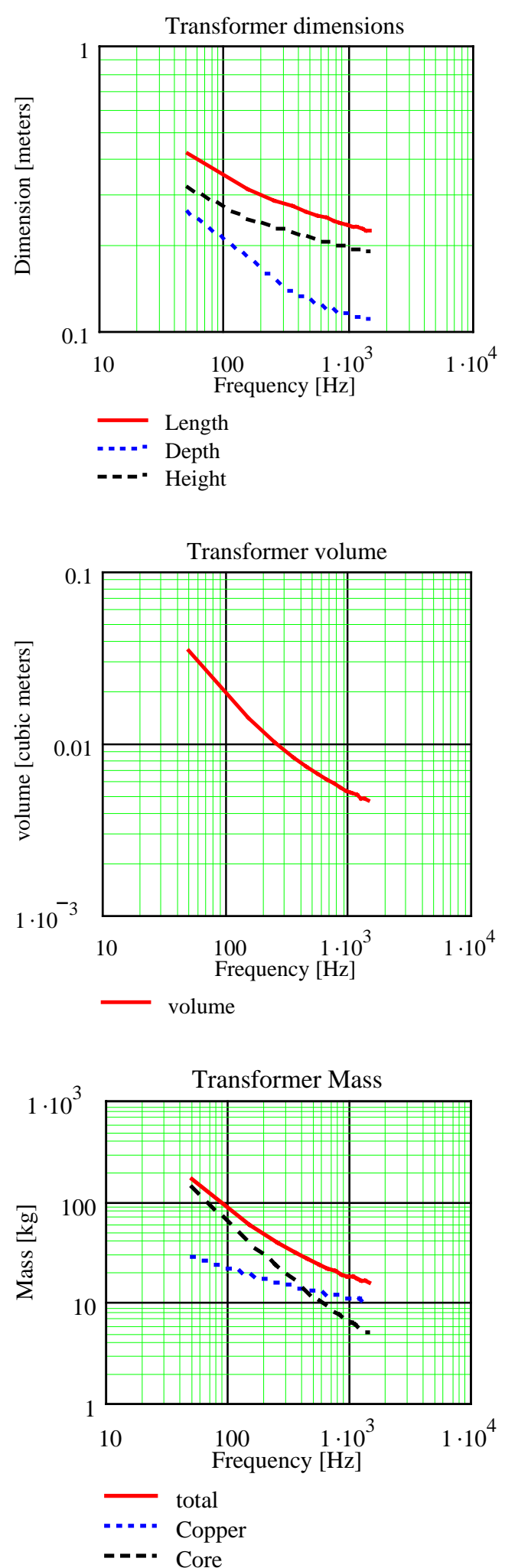

Figure 4. 50kVA transformer dimensions and volume 
Public reporting burden for this collection of information is estimated to average 1 hour per response, including the time for reviewing instructions, searching existing data sources, gathering and maintaining the data needed, and completing and reviewing the collection of information. Send comments regarding this burden estimate or any other aspect of this collection of information, including suggestions for reducing this burden, to Washington Headquarters Services, Directorate for Information Operations and Reports, 1215 Jefferson Davis Highway, Suite 1204, Arlington, VA 22202-4302, and to the Office of Management and Budget, Paperwork Reduction Project (0704-0188), Washington, DC 20503.

\begin{tabular}{|l|l|l|}
\hline 1. AGENCY USE ONLY (Leave blank) & $\begin{array}{c}\text { 2. REPORT DATE } \\
\text { August } 2004\end{array}$ & $\begin{array}{r}\text { 3. REPORT TYPE AND DATES COVERED } \\
\text { Technical Memorandum }\end{array}$ \\
\hline
\end{tabular}

\section{TITLE AND SUBTITLE}

Volume and Mass Estimation of Three-Phase High Power Transformers for Space Applications

\section{AUTHOR(S)}

Greg L. Kimnach

\section{FUNDING NUMBERS}

WBS-22-982-10-03

\title{
7. PERFORMING ORGANIZATION NAME(S) AND ADDRESS(ES)
}

National Aeronautics and Space Administration

John H. Glenn Research Center at Lewis Field

Cleveland, Ohio 44135-3191

8. PERFORMING ORGANIZATION REPORT NUMBER

\author{
E-14741
}

\section{SPONSORING/MONITORING AGENCY NAME(S) AND ADDRESS(ES)}

National Aeronautics and Space Administration

Washington, DC 20546-0001

10. SPONSORING/MONITORING AGENCY REPORT NUMBER

NASA TM-2004-213294

AIAA-2004-5711

\section{SUPPLEMENTARY NOTES}

Prepared for the Second International Energy Conversion Engineering Conference sponsored by the American Institute of Aeronautics and Astronautics, Providence, Rhode Island, August 16-19, 2004. Responsible person, Greg L. Kimnach, organization code 5450, 216-433-6251.

\section{2a. DISTRIBUTION/AVAILABILITY STATEMENT}

12b. DISTRIBUTION CODE

Unclassified - Unlimited

Subject Category: 20

Distribution: Nonstandard

Available electronically at http://gltrs.grc.nasa.gov

This publication is available from the NASA Center for AeroSpace Information, 301-621-0390.

\section{ABSTRACT (Maximum 200 words)}

Spacecraft historically have had sub- $1 \mathrm{~kW}_{\mathrm{e}}$, electrical requirements for GN\&C, science, and communications: Galileo at $600 \mathrm{~W}_{\mathrm{e}}$, and Cassini at $900 \mathrm{~W}_{\mathrm{e}}$, for example. Because most missions have had the same order of magnitude power requirements, the Power Distribution Systems (PDS) use existing, space-qualified technology and are DC. As science payload and mission duration requirements increase, however, the required electrical power increases. Subsequently, this requires a change from a passive energy conversion (solar arrays and batteries) to dynamic (alternator, solar dynamic, etc.), because dynamic conversion has higher thermal and conversion efficiencies, has higher power densities, and scales more readily to higher power levels. Furthermore, increased power requirements and physical distribution lengths are best served with high-voltage, multi-phase AC to maintain distribution efficiency and minimize voltage drops. The generated AC-voltage must be stepped-up (or down) to interface with various subsystems or electrical hardware. Part of the trade-space design for AC distribution systems is volume and mass estimation of high-power transformers. The volume and mass are functions of the power rating, operating frequency, the ambient and allowable temperature rise, the types and amount of heat transfer available, the core material and shape, the required flux density in a core, the maximum current density, etc. McLyman has tabulated the performance of a number of transformers cores and derived a "cookbook" methodology to determine the volume of transformers, whereas Schawrze had derived an empirical method to estimate the mass of single-phase transformers. Based on the work of McLyman and Schwarze, it is the intent herein to derive an empirical solution to the volume and mass estimation of three-phase, laminated EI-core power transformers, having radiated and conducted heat transfer mechanisms available. Estimation of the mounting hardware, connectors, etc. is not included.

\section{SUBJECT TERMS}

Transformers; Alternating current; Electric power; Power supplies; Voltage converters; Space power

\begin{tabular}{|c|c|c|}
\hline $\begin{array}{c}\text { 17. SECURITY CLASSIFICATION } \\
\text { OF REPORT } \\
\text { Unclassified }\end{array}$ & $\begin{array}{c}\text { 18. SECURITY CLASSIFICATION } \\
\text { OF THIS PAGE } \\
\text { Unclassified }\end{array}$ & $\begin{array}{c}\text { 19. SECURITY CLASSIFICATION } \\
\text { OF ABSTRACT } \\
\text { Unclassified }\end{array}$ \\
\hline
\end{tabular}

15. NUMBER OF PAGES

13

16. PRICE CODE 20. LIMITATION OF ABSTRACT 

